\title{
Liver Cancer pT3a TNM Finding v7
}

National Cancer Institute

\section{Source}

National Cancer Institute. Liver Cancer pT 3a TNM Finding v7. NCI Thesaurus. Code

C90161.

Liver cancer with multiple tumors more than $5 \mathrm{~cm}$ in greatest dimension. (from AJCC 7th Ed.) 